\title{
Expanding Institutional Urban Management Capacity at the Local Level: \\ Do Developing Countries Have a Chance?
}

\author{
Tarek Saad Ragab \\ Department of Architecture, Faculty of Engineering. \\ Alexandria University. Alexandria, Egypt
}


"Urban systems based on human settlements of 50,000 or 250,000 may be able to accommodate urban populations of 1 million, but they begin to break down at 4 million and are blatantly unworkable at 10 million. What is needed is a management capability more sophisticated and sensitive than anything developed to date"(Perlman.1993).

\begin{abstract}
Generally, the phenomena of institutional urban management weakness in less developed countries (LCDs) and correlation with macro economic context have been addressed in many literatures and researches (Brusi1990, Cheema 1993, Hardoy 1999). Fewer attempts, however, were made to investigate the problem's political contributory framework taking into account social and cultural aspects as well. This paper is concerned with investigating the impact of particular nature of political ideology, mechanisms, and structure anatomy on the institutional urban management capacities, especially transactional and operational controls activities in developing countries. The paper will briefly explain the basic framework of the urban management system in big cities of developing countries as they relate to the Egyptian context. A situational analysis of Egyptian framework gives some general evaluation and discusses implications. The theoretical underpinning will be implicated in a guidance for enhancing institutional urban management capacities in these developing countries.

Key words: urban planning; management; Egypt; developing countries.
\end{abstract}




\section{Coping with Over Urbanization Problems in LDC's:}

High rate of urban growth in less developed countries (LDCs) over the last four decades has led to many negative consequences: an increasing incidence of urban poverty and inequity, poor access to housing and such basic urban services as primary health care, sanitation, and water supply, the proliferation of slums and squatter on the peripherals and in old formal urban fabrics of the cities, and urban environmental degradation. The World Bank estimates that in 2002 about 90 percent of the total households in Latin America, 40 percent of those in Africa, and 45 percent in Asia are living in urban areas. Moreover, a growing proportion of residents of large cities are poor and powerless. (Worid Bank 2000).

On the other hand, the acuteness of these problems were amplified by the existing weakness of institutional urban-management-capacities of LDC's governments particularly at the local levels. The provision of urban land and basic urban infrastructures-and-services, and the management of day-to-day-transactional and operational urban jobs by different levels of governments could not keep pace with the rapid increase in the urban population. Owing to the speed with which urbanization has been taking place in these countries, govemments are overwhelmed by the immense urbanization problems that consume a great portion of their efforts and attention. Policies adopted by these countries to alleviate the pressure resulted from untamed urbanization were growth control measures, and other caps methods, mainly to slow rates of nural- to -urban migration and to diffuse urban population rather than expanding their capacities to effectively manage incremental demand of urban services and solve urbanization escalating problems. The result is more failure indicators: deteriorated and obsolete existing utlities, low levels of maintenance, shortcomings and substantial lagging in providing services, and poor crisis- management by localities and agencies. Unjustifiable overspending, insignificant cost recovery and cost effectiveness, and poor utilization of -usually- limited available resources are also other symptoms of these policies failure.

Urban Management System Capacity:

Many recent studies distinguishes urban growth management as an alternative policy approach that may be adopted instead of the evidently unsuccessful growth-control measures. They argue that better access to services and affordability of housing can be achieved through effective management of urban activities. (Mohsen 2002) On the contrary, many 
others suggest convincingly that housing policies, growth control measures, and mechanisms of infrastructures and services provision are the eggregate components of urban management process. While it is evident now that current adopted policies and structures have met little Eucosss (Gilbert\& Gugler 90), there is an increasing recognition that the inevilable growth of the cities and the solution to over-urbanization resulting problems should depend heavily on an effective system of urban management. The mere idea is that effective urban management system should have an expanded capacity to adopt successful policies and tools that achieve its objectives and exclude failure ones. According to Cheema, urban management capacity is the fiscal and administrative capabilities of different urban authorities to handle urban matters; performance standards, sensitivity to response to urban problems and community needs, and the effectiveness of employed policies and techniques to accomplish their objectives determine the management capacty of urban bodies and levels of government (Cheema 1993).

Cbviously, the fundamental objective of urban managernent system is to upgrade living standards of the communities' citizens through efficient planning, coordination, and better employment of available resources. The process of urban management comprises different levels of activities and degrees of involvement in decision making by concerned parties. The scale and nature of urban jobs and activities, encompassed by this definition, vary from strategic planning and policy formulation to management-and-operational control and transactional activities. Within this definition notion, citizens play the role of customers who purchase urban products that may vary in their nature (i.e. utilities and infrastructure projects, garbage collection service,.... etc.) and in their levels of complexity. (le, lowering levels of enviranmental pollution, enhancing recycling awareness ....etc.). Moreover, playing consumers of any physical or service products, customers usually expect high degree of satisfaction with their commodities. Effective urban management, consequently, should seek producing good urban products that shall neet customers' needs and satisfaction.

For the purpose of this paper, only urban management activities on the local levels are discussed and reviewed. Urban management, whenever mentioned, means only those types of activities and policies that are implemented by local authorities and agencies.

Without great exertion, and within the previously mentioned scope of urban management, the capacity of urban management can be 
investigated through two means: simple evaluative observation, and measuring the response of beneficiaries and their degree of satisfaction towards services supplied and environment maintained by different levels of government. However, these tow means are unreliable if we don't consider each case individually. While the standards of services: quality vary from certain community to another (depending on variables such es income and education levels, social, culture, health awareness, political atmosphere, and the amenities expected by citizens from their govemments) there are minimal standards that all involved parties. including citizens side, can agree upon and may typify urban management capacity. Within this previous concept perspective, citizens of some communities can describe their local govemment as "ineffective" because it fails to provide water main to their newly urbanized area where they migrated to long time ago, while citizens of other communities use the same term in describing their govemment because it fails to maintain high standards of environmental quality. Hence, defining ranges of priorities and setting forward standards of delivered services, sheltering definition and affordability, job opportunities, and social basic needs lists is a necessary pre-start step that should begun with before assessing management capacity of certain local authority.

Two major elements are found profoundly related to the capacities of urban management system: the state political ideology and the structure composition of urban management system. These two factors are discussed below:

\section{The State Political Jdeology and Correlation to Urban Management Capacity :}

The state political ideology has a significant impact on policy mechanisms and, consequently, on the effctivness of all adminstration aspects icluding those of urban management. On one hand it determines, to a great extent, the fiscal budget that is directed to finance service- and -utilities provision projects according to its list of priorities. On the other hand, urban bias is significantly determined by ideology nature. It influences policy makers attitudes and perception towards the significance of equally promoting the productivity of cities and allivieating urban poverty (Sheema 1993). In LDCs, where the prevailance of dernocracy is likely to be humble, policies tend to give preferentiality to certain urban centers (where rich and political eliets concentrate) to receive more services and modem utilities while other areas stay neglected and deprived due to their megar political weight and power. 
The state pattem of expenditure shows this urban bias ${ }^{1}$ which is also enhanced by deficient tax system that underestimates the role of local taxes in achieving urban equity. While these privileged urban centers became focal attraction poles for urban-to-urban and rural- to- urban migrants, other urban areas continued to decline and deteriorate.

On the other hand, political ideology influences the structure of the institutional organs and nature-and -levels of authorities given to different levels of govemment. Comparision of centralized and fedral types of govemments have been previously addressed in many litreature. However, within this research notion two major principle differences relate to urban management shall be addressed: first, the degree on which both types of govemmennt shall response to the community needs and, second, levels of performance effectiveness that can be achieved through different types of system government:

- Sensitive response to the community needs: federal type structure have always shown more sensitivity in responding to those needs as channels bind local problems and decisionsmakers are shorter and faster. Federal system govemment agenda also tends to concentrate on local problems and patronizing their citizens. Moreover, federal system government permits and maintains reasonable level of citizens interaction mechanism that ensures participation in decision-making process which, in turn, allows articulated and reliable solutions to the special community concems,

- Levels of performance effectiveness: comparision of both systems' performance shows indicators of achieving intended development. targets is more likely to occur in the federal system rather in the centralized system. Sharing burdens of responsibilities and problems between federal and local governments will allow federal govemment to focus on strategic planning, policy formulation, and achieving better levels of integration and coordination among players. This is reflected

\footnotetext{
Cairo, the capital of Egypt with an average population of 18 million residents (30\% of the whole population consumes $80 \%$ of the national growth income. The power gained by businessmen and the political elites creates a distorted partern of expenditure and urtan inequality. This resulting in creating more jobs and services in Cairo much more than other areas which .consequently, leads to a humengons, uncontroiled urban growth due rural to urban migration.
} 
directly in a better and effective performance of all parties handling dilferent urban matters.

\section{Urban Management Structure and Correlation to Urban Management Capacity:}

Well deaigned administrative structure definitely results in good management products. While evidences of correlation of a structurally well-designed administration and efficient urban management exist, some observers argue that other socio-economic factors shall have greater impact on urban management effectiveness and capacities. (Hayat \& Mohsen 1999). This opinion puts more emphasis on the importance of comprehending the strongly influential social, economic, and cultural local constrains to provide better quality services to communities. One prime characteristic of quality management is the ability to fully and efficiently utilize available resources and get reliable results.

The efficient structural design should acquire high levels of departmental interaction and coordination, strongly articulated procedures and onders. the ability to perform ongoing self action correction, reduced levels of bureaucracy, overcoming challenges of limited budget and social constrains, ensures cost effectiveness and cost recovery and, finally. responses sensitively to fulfill costumers needs and ambitions.

\section{The Egyptian framework:}

Political anatomy

The debate over political reforms necessity for the heavily centralized Egyptian governmental system is endless. However, the harsh reality raises serious concems regarding the probability of applying these political reforms especially with pressures of decline economy, social unrest. Political comuption, the absence of democracy and the decline role of public participation in decision-making are major obstacles hampering any attempt of political reform. This situation is also empowered by the desire of the businessmen and political elites to keep the current political ideology unchanged for their interest benefit. ${ }^{2}$

A typical political structure prototype of most developing countries is the Egyptian model. First, the prevalence of the heavily centralized type of government is the main feature that characterizes the state

\footnotetext{
'Atternpts to move govemmental agencies and ministries outside Cairo to Sadat city
} (110 K M from Cairo) since late 1970's have come to a dead end. Pressure practiced by businessmen and political clites was enormous. The result is increasingly uricortrotlable high rate of urban growth and continuous urban bias 
administration system. Second, system rigidity and distorted distribution of political power of both citizens majority and rulers. A huge political gab already exists in the Egyptian political cultural system between the rulers and the ruled. Citizens' lack of confidence and disappointment expresses a state of long and severe suffering and a dominant notion that the government does not work for their interests because simply they are poor and powerless. The government itself acts in a way that enhances this notion. While all the official speeches emphasize their interests in urban equity and targeting urban poor, attention of adminstrators towards urban problems and quality services and utilities provision are firstly directed to other sectors of the society that happen to posses wealth and political power.

The Egyptian System of Urban Managernent:

Egyptian urban environment possesses now all shortcomings and deficiencies of deteriorated urban environment. Urban management system, depending on its current capacities, is not able to cope with over urbanization problems. However, we can distinguish tow major periods of different performances. First, period of effective performance when quality services provision and highly standards urban and public affairs management were the major theme of institutional urban management plans. This period extended from the beginning of the century to the late 1950's. Administration domain was three major subdivisions:

- Govemorates (urban areas) mainly cities of Cairo and Alexandria.

- Modorias (rural sectors) headed by chief of police department.

- Border areas (nomally deserts) followed ministry of defense.

These were three types of local govemment having the same authorities but different nature related to the geographical characteristics and location of their jurisdictions. Governorates contained several municipalities (Balacliaat -singular: Bladiaa) that were responsible on all transactional and operation control activities. Supervisory activities and decision-making processes were undertaken by tow bodies:

- Board of Municipalities. Consisted of elected members in addition to a number of appointed members ( based on their pusts). This board was headed by governorate chief of police department. The board was concerned with managing the municipaiities affairs such as safety, health, education, agriculture, irrigation, roads. However, Boards of municipalities acquired no jurisdiction over the cities ${ }^{*}$ councils existed within the cities dornains. 
Cities ' Councils consisted of a majonty of elected members and a minority of appointed officiais based on their posts and specialties. Their major duties were policy formulation and strategic panning for their cities, in addition to coordinating the top fiscal and financial matters with the state government.

Three major factors contributed to provide better performance of urban management in this period:

1. Low rate of urbanization. This allowed urban management bodies to focus on upgrading standards of services and infrastructures provided to their communities.

2. Sound level of authority distribution between state govemment and local govemiments.

3. Effective law enforcement. Guaranteed lower rates of urban code and urban ordinance violations.

4. Strong macro and micro-economy,

Second, period of urban enviranment decline accompanied with decline in the urban management system performance started from late 1950's up to now. In 1960, the Egyptian Govemment endorsed the first law of local management. Ever since the law has been under ongoing modification. The main purpose of the law was to establish institutional administration system at different leveis to initially relates to the central govemment in Cairo. A new ministry was also added to the Egyptian cabinet (Ministry of Local Governance) to follow up the application of the new law. This ministry has been aiso a subject of change and even cancellation in some periods due to the continuous change of ideological believes of the regime rulers. Engineering and housing departments became responsible for all urban matters in cities ' municipalities (that their name changed from Bladiaat to Ahyaa) among many other adiministrative departments. Different levels of authority and power were given to many ministries representative departments in all cities and, in many cases, to other institutional bodies that created enormous conflicts and contradicting decisions. Municipal engineer (who is usually a civil engineer and lacks experience with urban affairs and adminstrative issues) possesses no jurisdiction to take immediate actions to halt simplist ordinance's violation. Instead, the ministry of interior (represented in its local polica departments) became the sole entitled authority that can prevent the violations while occurring and can, by using necessary force, correct the delinquent actions taken by code 
violators. ${ }^{2}$ The power given to the ministry of interior and consequently. to its local police departments encouraged code and ordinance violations because corrections are neither implemented nor supervised by urban administration. In many cases, police department will not carny out needed correction actions due to "lack af resources". No need to merition that connections and how much violator posses wealth and influence play a major role for not carrying out corrections actions. The consequences resulting in more violation."

The following is a review of four components of Egyptian urban management system found to be of greater impact on its capabilities to administer urban jobs at the local level: policy mechanism, structure and coordination, skills, and responsibilities and functions:

\section{1-Policy mechanism}

The existence of no articulated urban policy mechanism is one major root of marnagement limited capacity problem. This is true for both mechanisms of routine day-to day urban jobs and of strategic planning and policy formulation. Procedures are highly unstable and poorly described and documented. They are also subject to continuous change when officials and top mangers change their posts. This is also coupled with no public participation in decision-making, a centralized urban authority and a huge gab between local needs and authority response of to those needs.

\section{2-Strucutre and coordination}

As Cheema states, the strength and structure efficiency of the institutions responsible for planning and implementing urban policies and programs determine, to a great extent, the effectiveness of these polices and programs.(Cheema 1993). The proliferation of the govemmental and semi-govemmental agencies has led to a substantial lack of coordination, interaction, and consistency by the concemed agencies. Sectoral authorities, for example, tend to provide infrastructure facilities without ensuring that local governments have the capacity to perform the needed adequate maintenance programs. It is due partially to the fragmentation of the institutional machinery that capital works programs have often not been effectively linked with operational policies such as

\footnotetext{
'Local poliec forces are responsible for demolishing the non-permitted floors in newly -built and cout of foot-prints and set-back properties.

'Housing and urban code violations were 277884 violations through year 1999 at Alexandras Alexandria Govemorate Housing Depurtmenl)
} 
services pricing and cost recovery. These contradictory decisions and confilicts over areas of influences resulting in ineffectiveness and incapacity to function. While important components of the urban institutional capacity in a country are horizontal and vertical coordination among the concemed agencies and bodies, it is found that low levels (and likely no levels) of coordination and interaction exist between different urban departments (horizontally) and state and local govemments (vertically). This phenomena extends to contain all administration levels including those of higher ranks. Lack of coordination results in contradicting decisions, which are likely to be expensive and inefficient. Failure of concemed parties to interact has a significant detrimental impact on the principles of cost effectiveness and cost recovery ${ }^{5}$ and, consequently, limits the chances of fully utilization of the limited budgets devoted for different types of projects and services.

\section{3-Skillis}

\section{3-1.Humman relations skills}

In the Egyptian administration system, officials and employees will never see the citizens as a customers that should seek every possible mean to meet their needs and satisfaction. In fact, complains of bad and tough treatment by employees is a normal event in the Egyptian social life. This is one component of certain cultural heritage and social deficiencies generated from the colonial era that put rulers (represented in the governmental officials) in a higher rank than the ordinary citizen; personal contact with govemmental employees, accordingly, will consider a plight by most of the citizens.

\section{3-2- Technical skills}

Lack of basic technical skills of urban management officials and employees represents another major root of the problem. It results from poor training, non-specialty, and non-proper education. This phenomenon characterizes most employees including those of higher ranks posts. It is also coupled with the existence of no motive for job perfection or job-skills upgrade. This is also encouraged by the existence of no effective means for monitoring employees' misconduct, and red tape and policy inadequacies in staff development. On the other hand, personnel practices are usually characterized by unequal

\footnotetext{
"It is a nomal scene in all Egyptian cities that streets are being paved sevent times with very small time intervales as every utility provider do his own work with no coondinition with other utilities providers managed by localitios
} 
promotion opportunities to various civil services cadres, and political intervention and favoritisms in recruitment.

4. Responsibilities and Functions:

4-1 Bureaucracy, comuption, and red tape:

Because of the immense power of bureaucracy and red tape, time and efforts spent to take needed actions to deal with certain problem is humongous, resulting in unimaginable delay that makes the problem magnitude amplifies. Projects and services take decades to be implemented and their budgets remains untouched for years waiting to be spent.

Virtually, all administration sj'stems have bureaucracies that are different in degree and power (Garcia-Zamor\&Renu Khator 1996) Five different factors contribute to increase bureaucracy of the Egyptian urban management system:

- Govemment centralization: acquire more bureaucracy due to the integration in one rigid system.

- Communal and public sector: as all urban functions are performed by the Egyptian govemment, this situation increases its burden in light of its limited capabilities and limits its role to focus on management only.

- Unbalanced dispersal of armed forces political power: the armed forces is identified as a political power. This tends to increase bureaucracy due to this unbalanced power situation.

- Poor dynamic of official's career positions in the administration structure.

- Long term-officials careers of public services.

Government's attempts to reduce levels of bureaucracy have proven failure due to the intense concentration of the govemment and the fear of social unrest that may be increased due to the consequences of reform actions.

Corruption is widely spread in the institutional management system. Poor monitoring system and very low paid wages drive many officials to corrupt including those of higher rank posts. Bribing and under table money is a common act to go beyond laws with the existence of weak and "conditional "law enforcement. Housing and urban land provision crises empowering corruption and employees misconducts. These unorthodox means guarantee gaining more profits and privileges taking 
advantages of the unpunished code and ordinance violations conducted by landiords of properties.

\section{4-2 Data collection and management.}

Govemorates, townships, and infrastructure-supply agencies lack basic data of most of their cities and neighborhoods. This data is the comer stone to provide services in efficient, organized, and non-contradicting manner. While it is understandable how collecting, managing and utilizing these data cost (through electronic base- media or hard copies media), especially with the very fide budget devoted for El-Ahyaa, some lower rank public officials don't "wan"' to believe it is feasible than using trial- and error- method, which they apply on all working aspects such as providing new services, upgrading existing insufficient and obsolete services or simply paving a new road.

\section{4-3 Fiscal capacity:}

One of the most pressing problems in urban management is weakness of the financial capacity of urban local governments. Restricted taxing and revenue-raising actions by local government hamper attempts of promoting financial capacity. Lack of technical assistance and training to local officials, meager system of intergovemmental transfer and allocation of funds from central to local governments are also factors added to limit fiscal capacity of local government.

\section{4-4 Management capacity:}

Lack of clarity in the allocation of functions and responsibilities to agencies has also impeded the effective delivery of urban infrastructure and services. Responsibilities are often allocated to agencies without delineating mechanisms through which their assigned roles are to be coordinated with those of the existing agencies.

\section{Transactional activities.}

Performance within this category of activities represents the most apparent evidence of govemment limited management capacity. Weak performance categorizes managing such activities at all Egyptian cities.

Throughout different city-size -distribution, such critical activities may change with city size. While small size cities may suffer more from the scarcity of skilled management and technical officials, (ө.g. experienced zoning officers (Architects) and from the absence of routine management procedures and efficient budget 
accounting systems, metropolitan Cairo and Alexandria experience immense difficulties of managing immense growth and development under strong population pressure.

Operational control:

6. Another incapability indicator of local authority to administer ordinary services is the obvious low hygienic standards of cities. Although many municipalities are provided with state- of -the -art cleaning machinery local management fails to meet the minimum standards of street hygienic levels. Moreover, very little official attention is paid to other health and life threatening hazardous such as disposing, transporting and handling hazardous materials. Many Local officials perceive that addressing such issues is a kind of luxury with the deteriorated conditions of the major services. Consequently, no precaution rules (even some exists by laws) are applied neither by health department nor by police. Residents threw their garbage in the streets in collection centers where it accumulates and left for days and sometimes more. The remainder is throw into informal dumpsites, outskirt vacant lots, and rivers. In some deprived and outskirts cities approximately $60-80$ per cent of households7 receive running water, but for only a fow hours every other day. Unpaid for water is around 70 per cent of the total supply. No sewage treatment occurs, and rain and sanitation pipes often join resulting in the mixture of sewage and storm runoff.

\section{What Can LDC's Do?}

In this part of the paper we will attempt to answer two fundamental questions: Do LDC's have a chance? and what can they do to expand

\footnotetext{
In the 1980s, Cairo Regional Water Company designed a new water main to supply a part of the city poorly served by an old main. A typing error led to the use of piping of too low pressure. On inauguration it exploded. The Water Company has gone back to using the old main and provides substandard service.
}

Espicially outside major urban centers and at the outskirts of big and meduimsize cities. 
their urban management capacities? To answer these questions two different facts should be primarily brought to light. First, employing imported copies of management westem models by LDC's will definitely lead to an evident failure as the existing political, social, and economical substantial differences will drain these models from their contents. Second, we should not expect, or aim to achieve, a drastic change in urban management capacities by employing locally-suited approaches and socio-economic reforms. Gradual advancement will suit LCD's special conditions and ensures sustainable development.

it is comprehendible that we can't separate attempts to improve one single aspect of a certain authority, through different sorts of reforms and policies, from improving the overall context of the country. Therefore, it is of a relative importance to set objectives of development within each country's case and its tendency. The most important factor that may give hope for development chances in LDC's is the existence of both public and political elites desire for improvement.

The following is a presentation of four major concepts which may be adopted by LDC's countries to expand their urban management capacities at the local levels. These four measures are found to be targeting the most salient urban management weaknesses:

1-Developing a Reasonable Strategy and Aotion Plan:

Reviewing institutional management structures in many developing countries incicates a widening gab between planning bodies and direct responsibility for the actions that determine outcomes. It is normal that these bodies frequently creale voluminous plans for urban development and environmental improvement that have little relevance to implementation. Action plans should set lower, more appropriate and flexible standards for development. Local agencies must become involved in the priority setting process and multi-sectoral capital budgeting to produce efficient urban operations. The capital budgeting process offers the only forum in which decision-makers can sit together and plan future development seriously.

\section{2-Improving Uiban Management Accountability:}

In practical terms, urban management accountability means creating " feedback loops " between the suppliers of urban "products" (policy makers, planners and managers....) and the end consumers (households, businesses, and industries). The 
introduction of market based mechanisms aautonomy and competition into urban services (and management as.well) can create such feedback loops.

Competition represents the most important market- based strategy for promoting quality and increasing accountability in supplying urban services. This applies on all aspects starting from hiring low rank employees to contracting firms for modifying or solving master plan problems. Greater competition on managing demand can help the infrastructure sector break out of the low - level equilibrium trap that dominates urban management of services in much of developing countries. Low levels of services dampen willingness to pay and, in tum, reduce cost recovery and financial seif-sufficiency. The competitions generated amongst services suppliers shall only benefiting the end consumers through providing reasonable and highiy standard services and utilities. Within this model notion, bodies and agencies that provide services should be chosen on competitive bases taking all needed consideration to prevent market manipulation. The role of the urban managers and administrators should be only focusing on coordinating the process of services submittals and not to undertake physical works. Therafore, the concept of "coordination" should be clarified and enhanced in the conscious of urban managers and officials.

\section{Enhancing Urban Management Autonomy}

Autonomy can help combat vices. ${ }^{15}$ An autonomous institution has clearly defined levels of service, areas of operation-andjunsdiction, and independent financing mechanisms. These former characteristics make assessment of performance possible. An agancy that performs well meets its institutional mandate within its financial and budgetary resources in addition to maintain highly services standards.

Increased urban managerial autonomy at the local level can also clarify and separate the supply and regulation of services. in LDC"s, central government tends to act as a supplier and a regulator of services and projects in the mean time. In eifect the government acts as 'both gamekeeper and poacher' creating conflicts of interest. in the Egypt in 1989, the privatization of water supply revealed such a problem. Responsibility for the quality of water remained in the government's hands while privale firms assumed responsibilities for its supply. After 1989, 
the number of fine levied for illegal discharges and violations standards more than doubled.

\begin{abstract}
4-Adopting Total Quality Evaluation and Correction Measurements Tools:

Continuous Performance Efficiency Evaiuation (CPEE) and Action Correction Protocol (ACP) may be considered essential tools to promote managerial performance and quality services provision. On the other hand, it is important to promote the significance of these processes into the awareness of urban managers and employees. Assessing urban managers and employees credentials should heavily depends on how they are responding to performance modification depending on the outcomes resulted from employing end- product evaluation methods
\end{abstract}

\title{
Conclusion:
}

Reviewing urban management performance of localities in LDC's has identified political interference and a lack of efficient management autonomy as two of the chief sources of institutional urban management failure. Political pressure has forced utilities to set services prices below the cost of production which is justified by maintaining social stability, to appoint managers and employees with connections but poor technical or managerial, skills and to pad employment rolls in order to provide patronage. Govemments also tend to act as a utility provider rather than a regulator.

It is evident now that linking insufficient funds to limited management capacities is no longer valid. Evaluating localities performances in LCD's shows excessive expenditure in final cost of executed projects due to lack of coordination, and the poor quality of design and specifications. Providing quality utilities and services with less expenditure needs higher levels of horizontal and vertical coordination, better quality design and higher specifications even though all these seem to consume more funds. On the other hand, adopting effective system of monitoring projects execution and specification, in addition to enabling prompt law enforcement mechanism will definitely resulting in cutting costs and ensure quality services and infrastructure projects.

A set of four principles has emerged from practice and the literature to readdress these institutional failures and to expand urban management capacities at the local level: 
1-Set urban prionties by measuring, assessing and prioritizing urban needs and developing action plans.

2-improve the provision of infrastructures and services by mainly implementing economic reforms (a market based model) that support autonomy, competition, and appropriate pricing and effective regulation. 3-Increase accountability through socio-political reforms that focus on decentralisation, participation, targeting poor people and social marketing.

4-Finance this work in such a way that it moves service provision towards market principles and away from patronage.

Bibliography:

Atkinson, A. (1991), Principles of Political Ecology, London, Belhaven.

Brown, L., H. Kane and E. Ayres (1993). Vital Signs 1993. The Trends that are shaping The Future, Washington D.C. World watch Institute. Bauer, RA. (ed)(1966) Social Indicators, Cambridge, MA, MIT Press. Prank. (1990), We need a global mixed economy and a global Public Sector, International Foundation For Development Altematives (IFDA) Dossier.

Meier, R. (1993). The way to sustainability for poor cities, Environment and Urbanization,

Korten. D.C. (ed) (1987). Community Management Asian Experience and Perspectives, West Hartford, Kumarian Press.

Stohr, W.B. (1981), Development From blow: Bottom- up and peripheryinward development paradigm' in Stohr and Taylor (1981). 